\title{
Climate Change In Indonesia (Case Study : Medan, Palembang, Semarang)
}

\author{
Yadi Suryadi ${ }^{1 *}$, Denny Nugroho Sugianto ${ }^{1,2}$ and Hadiyanto ${ }^{1,3}$ \\ 1 Master Program of Environmental Studies, School of Postgraduate Studies, Diponegoro University Semarang \\ 2 Oceanography Department, Faculty of Fisheries and Marine Science, Diponegoro Univers ity Semarang. \\ 3 Chemical Engineering Department, Faculty of Engineering, Diponegoro University Semarang.
}

\begin{abstract}
Indonesia's maritime continent is one of the most vulnerable regions regarding to climate change impacts. One of the vulnerable areas affected are the urban areas, because they are home to almost half of Indonesia's population where they live and earn a living, so that environmental management efforts need to be done. To support such efforts, climate change analysis is required. The analys is was carried out in several big cities in Indonesia. The method used in the research was trend analys is of temperature, rainfall, shifts in rainfall patterns, and extreme climatic trend. The data of rainfall and temperature were obtained from Meteorology and Geophysics Agency (BMKG). The result shows that the air temperature and rainfall have a positive trend, except in Semarang City which having a negative rainfall trend. The result also shows heavy rainfall trends. These indicate that climate is changing in these three cities.
\end{abstract}

\section{Introduction}

Indonesia's maritime continent is one of the vulnerable areas to the impacts of climate change. Temperature changes, rainfall changes, sea level rise, increased hydro-meteorological disasters, robust, infrastructure damage, increased fire hazard, ecosystem damage, health problems and increased discomfort for residents $[1,2,3,4,5]$ and directly or indirectly affect the economy.

One of the most vulnerable areas affected is city. Cities are vulnerable to climate change both because extremes weather events can be distrutive to complex urban systems and because so much of the world's urban population live in low-lying coastal areas, particularly in Asia[6], so environmental management efforts need to be done. To support these efforts, it is necessary to identify climate change. Climate change refers to changes in climatic conditions that can be identified (eg by using statistical tests) by changes in the mean and / or variability of their properties, over a long period, usually decades or longer either due to natural variability or as a result of human activities[7]

Climatic factors that become the main indicators of climate change in Indonesia are changes in patterns and intensity of temperature and rainfall parameters. ${ }^{8}$ Indications of climate change can be done with time series analysis that can provide information on trends, cycle analysis or shifts around the average in the long term.
The study aims to identify climate change in the cities of Semarang, Medan and Palembang based on trend patterns, inter-time analysis (decadal) and analysis of rainfall tendencies at the height of the rainy season and at the peak of the dry season.

\section{Material and Method}

\subsection{Location}

The study sites were Semarang, Medan and Palembang.

\subsection{Data}

This research was done by processing the rainfall data and the temperature of the land. The data were secondary data obtained from BMKG observation / meteorology station. The data were downloaded from http //: www.dataonline.bmkg.go.id. Semarang (Period 1985-2016), Medan City (period 1982-2016) and Palembang (Period 1980-2016).

\subsection{Analysis Stages}

This research performed the following stages:

\subsubsection{Normality Test}

This test aimed to know the distribution of data distribution compared with the normal data distribution using Kolgomolov-smirnov method

\footnotetext{
Corresponding author: yadsur80@gmail.com
} 


\subsubsection{Trend Analysis}

The trend analysis used a simple regression using MS Office Excel 2013 to the annual, monthly and seasonal data.

\subsubsection{Analyze the 10-year (decadal) data}

Analyze the 10-year (decadal) data by dividing the period of data into Period I (1987-2006); Period II (1997-2006) Period III (2007-2016) then performing the average difference test ( $t$ test) temperature and rainfall per data period. This test was to determine whether or not there was an average change as an indication of climate change

\section{Results and Discussion}

\subsection{Temperature}

\subsubsection{Normality Test of Data Distribution}

Table 1 Test of Normality of Annual Temperature

\begin{tabular}{|c|c|c|c|c|c|c|}
\hline & \multicolumn{3}{|c|}{$\begin{array}{c}\text { Kolmogorov- } \\
\text { Smirnov }^{\mathrm{a}}\end{array}$} & \multicolumn{3}{|c|}{ Shapiro-Wilk } \\
\hline & Statistic & $\mathrm{df}$ & Sig. & Statistic & $\mathrm{df}$ & Sig. \\
\hline Semarang & 092 & 32 & ,200* & ,963 & 32 &, 332 \\
\hline Medan &, 123 & 32 &, $200^{*}$ & ,952 & 32 &, 168 \\
\hline Palembang &, 115 & 32 &, $200^{*}$ & ,969 & 32 & ,485 \\
\hline
\end{tabular}

Normality test results for the annual temperature data using Kolmogorov-Smirnov and Shapiro-Wilk for the three cities showed a significance value $>0.05$. This value indicates that the residual regression model is normally distributed. So it can be done for further parametric test.

\subsubsection{Temperature Trends}

The trend of temperature change in the three cities is calculated using trend line on Microsoft excel, the result is a positive trend in the three cities (Figure 1). Semarang City showed an upward trend of $0.0279^{\circ} \mathrm{C} /$ year (1985-2016), Medan City positive trend of $0.00331^{\circ} \mathrm{C} /$ year $(1982-2016)$ and Kota Palembang positive trend of $0.0212^{\circ} \mathrm{C} /$ year $(1980-2016)$. This is consistent with the average rise in surface temperatures of Indonesia's land area of $0.016{ }^{\circ} \mathrm{C} /$ year $^{5}$, while the Earth's surface temperature increased by $0.85{ }^{\circ} \mathrm{C}(0.65$ $1.06^{\circ} \mathrm{C}$ ) during the period of $1880-2012$ or $0.002879 /$ year ${ }^{9}$.

\subsubsection{Temperature Patterns}

Temperature patterns obtained by summing the temperature data per month during the data period then obtained the results as shown in Figure 2. Temperature patterns in Semarang and Palembang City have two peak temperatures, namely in May and October and peak minimum temperature at the peak of dry season and rainy season. While in Medan only has one peak of maximum temperature in May and a peak of minimum temperature in December-January

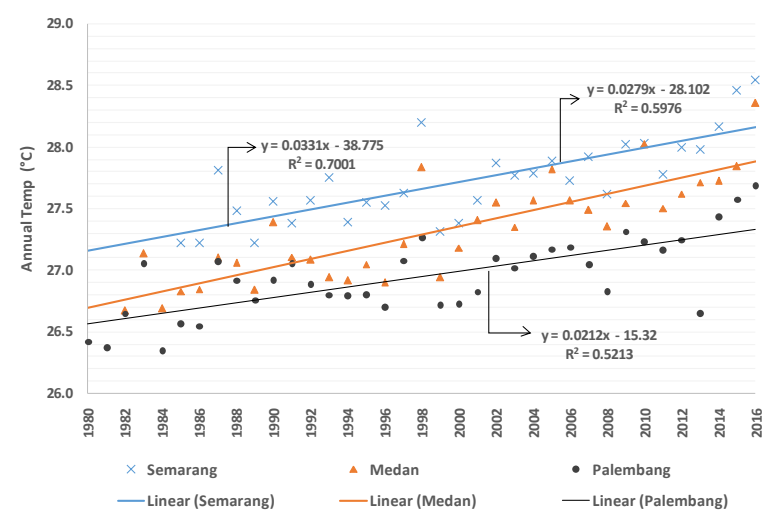

Fig. 1. Temperature Trends

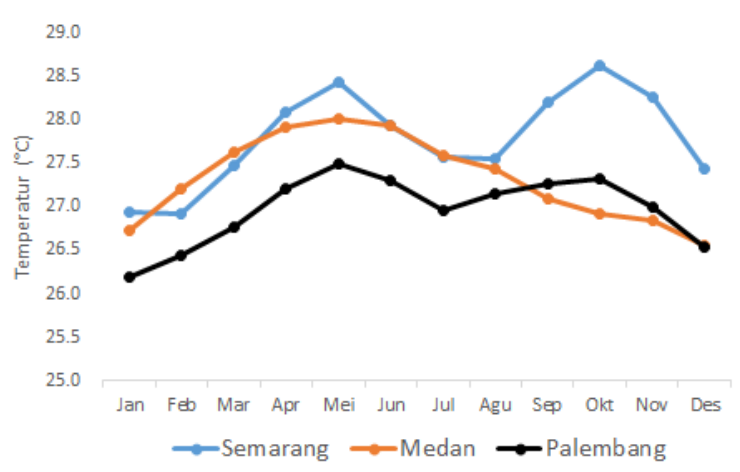

Fig. 2 Seasonal Temperature Pattern

\subsubsection{Different Test of 10 Year Annual Temperature}

In order to obtain temperature change information for a shorter period of 10 years, the data are grouped into three periods, and then the temperature difference test is done between periods as the result in Table 2 .

Table 2 Test of Differential Temperatures of 10-Year Average

\begin{tabular}{lrrrrl}
\hline \multicolumn{1}{c}{$\begin{array}{c}\text { City/ } \\
\text { Period }\end{array}$} & $\begin{array}{c}\text { Test } \\
\text { statistic }\end{array}$ & df & $\begin{array}{c}\text { t } \\
\text { Table }\end{array}$ & $\begin{array}{c}\text { Sig. } \\
\text { (2 Tailed) }\end{array}$ & Conclusion \\
\hline Semarang & & & & & \\
III-II & 8.573 & 11 & 2.201 & 0.000 & Reject $\mathrm{H}_{0}$ \\
II-I & 5,960 & 11 & 2.201 & 0.000 & Reject $\mathrm{H}_{0}$ \\
III-I & 23,833 & 11 & 2.201 & 0.000 & Reject $\mathrm{H}_{0}$ \\
Medan & & & & & \\
III-II & 8,729 & 11 & 2.201 & 0,000 & Reject $\mathrm{H}_{0}$ \\
II-I & 9.519 & 11 & 2.201 & 0,000 & Reject $\mathrm{H}_{0}$ \\
III-I & 32,729 & 11 & 2.201 & 0,000 & Reject $\mathrm{H}_{0}$ \\
Palembang & & & & & \\
III-II & 9,546 & 11 & 2.201 & 0,000 & Reject $\mathrm{H}_{0}$ \\
II-I & 8,317 & 11 & 2.201 & 0,000 & Reject $\mathrm{H}_{0}$ \\
III-I & 22,905 & 11 & 2.201 & 0,000 & Reject $\mathrm{H}_{0}$ \\
\hline & & & & &
\end{tabular}


The above difference test obtained $t$ value greater than the critical value ( $\mathrm{t}$ table) with significance $<0.05$, this means that the decision can be taken that $\mathrm{H} 0$ hypothesis is rejected for all periods in each city, so it can be concluded that there is a significant difference between Period III-II, II-I and III-I. Because the value of $t$-statistic positive indicates that the average temperature of Period III is higher than period II and Period I. Similarly period II has a higher average temperature than period I. Thus the temperature in the three cities consistently increased from the period previous.
(Medan 14,583 mm/year and Palembang 4,814 $\mathrm{mm} /$ year)

\subsection{Monthly Rainfall}

Normality test (Table 4) showed significance value> 0.05 either Kolmogorof-Smirnov or Shapiro-Wilk test showed that the rainfall data in the three cities followed the normal distribution.

Further analysis were conducted on monthly rainfall trends (Table 4 ). The negative rainfall trend in Semarang city from $1985-2016$ periods is also
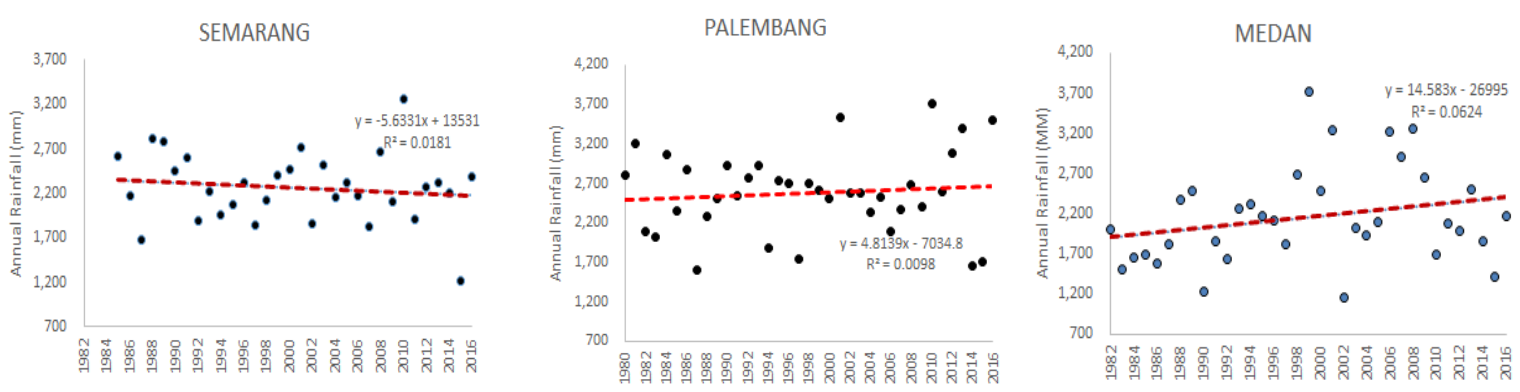

Fig. 1. Annual Raifall Trends

However, rising urban temperatures can be attributed to the effects of urban heat island (UHI) effects on temperature measurement data (Bappenas, 2010). Some factors affect UHI including urbanization, land cover change rate. Nevertheless, the impact is mutually reinforcing with climate change, as global climate change will exacerbate UHI's effects in urban areas[7].

\subsection{Rainfall}

\subsubsection{Normality Test of Annual Rainfall Data}

Table 3 Test of Normality of Annual Rainfall Data

Tests of Normality

\begin{tabular}{|l|r|r|r|r|r|r|}
\hline \multirow{5}{*}{} & \multicolumn{3}{|c|}{ Kests of Normality } \\
\cline { 2 - 7 } & \multicolumn{2}{|c|}{ Kolmogorov-Smirnov ${ }^{\mathrm{a}}$} & \multicolumn{3}{|c|}{ Shapiro-Wilk } \\
\hline Semarang &, 076 & 32 &, $200^{*}$ &, 984 & 32 &, 900 \\
Medan &, 112 & 32 &, $200^{*}$ &, 963 & 32 &, 336 \\
Palembang &, 109 & 32 &, $200^{*}$ &, 957 & 32 &, 220 \\
\hline
\end{tabular}

*. This is a lower bound of the true significance.

a. Lilliefors Significance Correction

Normality test (Table 3) showed significance value $>0.05$ either Kolmogorof-Smirnov or ShapiroWilk test showed that the rainfall data in the three cities followed the normal distribution.

\subsubsection{Annual Rainfall Trends}

The annual rainfall trends in the three cities (Figure 3) show a negative trend in Semarang city of $-5.6331 \mathrm{~mm}$ / year, while in the other two cities are positive trend explained by the monthly rainfall which is dominated by negative trend. There are 7 months with negative trends and 5 months with positive trends. In general, the city of Semarang has decreased both in the rainy season and in the dry season.

Table 4 Monthly Rainfall

\begin{tabular}{lcccccc}
\hline Month & \multicolumn{6}{c}{ Tren } \\
\cline { 2 - 7 } & Smg $^{\mathbf{1}}$ & $\mathbf{R}^{\mathbf{2}}$ & $\mathbf{M d n}^{\mathbf{2}}$ & $\mathbf{R}^{\mathbf{2}}$ & $\mathbf{P I b}^{\mathbf{3}}$ & $\mathbf{R}_{\mathbf{2}}$ \\
\hline Jan & -2.785 & 0.016 & -0.828 & 0.0063 & $\mathbf{2 . 4 3 2}$ & 0.086 \\
Feb & -0.588 & 0.001 & -0.4038 & 0.002 & -0.284 & 0.001 \\
Mar & -2.803 & 0.089 & $\mathbf{1 . 5 9 8 4}$ & 0.0223 & $\mathbf{0 . 7 5 8}$ & 0.003 \\
Apr & $\mathbf{2 . 1 9 2}$ & 0.080 & $\mathbf{0 . 5 7 1 7}$ & 0.0062 & $\mathbf{3 . 0 0 7}$ & 0.146 \\
Mei & $\mathbf{0 . 8 1 3}$ & 0.010 & $\mathbf{1 . 6 2 2 6}$ & 0.025 & -1.254 & 0.029 \\
Jun & -1.636 & 0.024 & $\mathbf{0 . 9 9 5 8}$ & 0.014 & -1.021 & 0.015 \\
Jul & $\mathbf{0 . 4 2 3}$ & 0.005 & $\mathbf{2 . 7 1 5 5}$ & 0.0776 & -0.907 & 0.017 \\
Aug & -0.651 & 0.010 & $\mathbf{3 . 2 5 7 7}$ & 0.0878 & $\mathbf{0 . 0 3 8}$ & 0.000 \\
Sep & $\mathbf{1 . 3 9 1}$ & 0.022 & $\mathbf{1 . 4 5 5 8}$ & 0.0219 & -1.477 & 0.019 \\
Oct & -1.477 & 0.018 & $\mathbf{3 . 7 5 1 3}$ & 0.201 & -0.049 & 0.000 \\
Nov & $\mathbf{1 . 1 6 7}$ & 0.012 & -1.0876 & 0.0116 & $\mathbf{1 . 7 1 2}$ & 0.017 \\
Des & -2.937 & 0.054 & $\mathbf{0 . 9 3 3 7}$ & 0.005 & $\mathbf{1 . 8 5 9}$ & 0.034 \\
\hline
\end{tabular}

Medan city showed positive rainfall trend in period 1982-2016 with 9 month positive trend and 3 month negative trend. The high rainfall increase occurred in August (slope 3.2577) and October (slope 3.37523).

While Palembang has rainfall with a rising trend with relatively small increase of the city of Medan with the number of months with the positive trend equal to the number of months with negative trends. The increase in rainfall occurs in the rainy season and decreases rainfall during the dry season. The highest increase in rainfall in January $(2,432)$ and April $(3,007)$. 


\subsubsection{Monthly Decadal Rainfall Patterns}

In Indonesia, rainfall patterns are influenced by several factors, including monsoon, Inter-Tropical Convergence Zone (ITCZ), IODM, ENSO, and other regional circulation found in the Pacific Ocean and Indian Ocean[8]. According to Aldrian and Susanto, [10] Indonesia's rainfall pattern is divided into three main regions as follows: a) Region $\mathrm{A} /$ Monsoonal characterized with a one peak rainfall season between November-March; b) Region B/ Equatorial characterized with two peak rainfall season in OctoberNovember and March-Mei; c) Region C/ Local climate area, it is characterized with one peak in June-July and one trough in November-February.

Monthly decadal rainfall analysis used to find out rainfall pattern changes. From Fig. 4 shows that Semarang is included in region A, characterized with a clear rainy and drought pattern with a rainfall peak in December-January-February (DJF) and peak dry season in June-July August (JJA). While the climate pattern of Palembang and Medan is an equatorial climate pattern, characterized with two rainfall peaks (October and March). In this climate pattern most of the year is the rainy season.

From the 10-year trend of monthly rainfall in Semarang city, there was a consistent decrease of rainfall during rainy season (DJF) period 1996-2006 and 2006-2006 to rainfall period 1986-1996 (baseline), decreasing rainfall in DJF period Especially in December-January while in February experienced an increase in the period 1996-2006 and then decreased in the period 2006-2016 although the value is still above the baseline period.

Climatic patterns in the city of Medan are included in an equatorial climate type characterized by two peak rainy season in July-December with two peaks of the nearby rainy season. The Medan rainy season observed in the period 1986-1996 occurred in August and November, during the period 1996-2006 peak rainy season shifted in october and December, and currently peak rainfall is still in the same month with the tendency of decline in month October and consistent increases in December and the highest rainfall in the period 2006-2016.

From these conditions can be searched the conclusion whether there is a change or not, it is indicated by the difference in the average of each period. To take conclusion then $t$ test is performed to climate data per period at $95 \%$ confidence interval (table 5).

In general there is no real difference between the period III to II and Period II against Period I in the city of Semarang and Palembang. While in the city of Medan there is a significant change in rainfall between periods

The quarterly rainfall shows the current condition in Semarang city decreasing rainfall trend in rainy season $(-14.54)$ and the increase of rainfall in dry season / JJA (7.5905), The same thing happened in the city of Medan experienced a decreasing trend of rainfall in the dry season / DJF (-7.6673)

Table 5 Test of Different Rainfall 10 Year

\begin{tabular}{ccclllllll}
\hline \multirow{2}{*}{ Periode } & \multicolumn{3}{c}{ Semarang } & \multicolumn{3}{c}{ Medan } & \multicolumn{2}{c}{ Palembang } \\
\cline { 2 - 9 } & $\begin{array}{c}\mathbf{t} \\
\text { Statistic }\end{array}$ & $\begin{array}{c}\text { T- } \\
\text { table }\end{array}$ & \multicolumn{2}{l}{ Conclusion t-Statistic } & T calc & Conclusion & t calc & $\begin{array}{c}\text { t } \\
\text { table }\end{array}$ & Conclusion \\
\hline III-II & $-0,131$ & 2.201 & Accept $\mathrm{H}_{0}$ & $-2,203$ & 2.201 & Reject $\mathrm{H}_{0}$ & 1,859 & 2.201 & Accept $\mathrm{H}_{0}$ \\
II-I & $-0,790$ & 2.201 & Accept $\mathrm{H}_{0}$ & 2,933 & 2.201 & Reject $\mathrm{H}_{0}$ & 0.344 & 2.201 & Accept $\mathrm{H}_{0}$ \\
III-I & $-0,539$ & 2.201 & Accept $\mathrm{H}_{0}$ & 1.474 & 2.201 & Accept $\mathrm{H}_{0}$ & 1,390 & 2.201 & Accept $\mathrm{H}_{0}$ \\
\hline
\end{tabular}
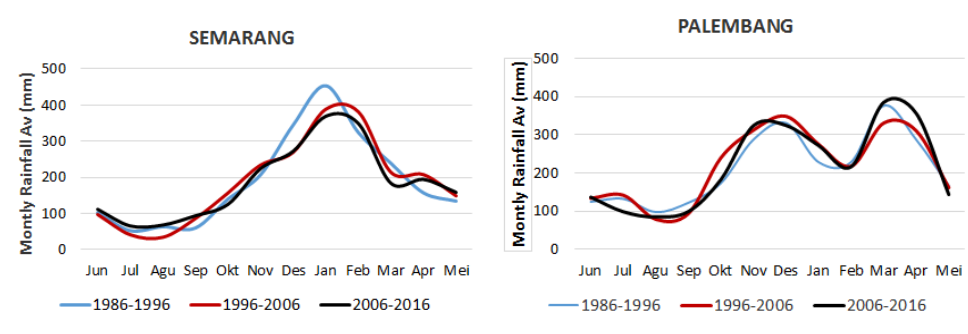

Fig. 4 Decadal Rainfall Patterns

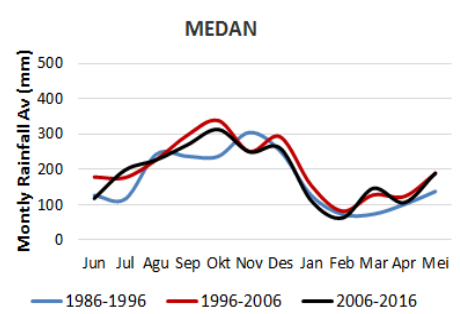

—1986-1996 —1996-2006 -2006-2016

\subsubsection{Test of Different Seasonal Rainfall}

To ensure the significance of the changes that occur, the statistic test of annual rainfall between decades was done. Table 6 presents the results of different test between decades showing that only the city of Medan that has an absolute value $\mathrm{t}$ arithmetic greater than $\mathrm{t}$ table so that it can be drawn conclusion H0 In rejection, it means that there are significant differences in period I - Period II (rainfall increase) and Period II Period III (rainfall decrease) 


\subsubsection{Seasonal Trends}

In general, the seasons are derived to rainy season (December - January - February / DJF), intermediate seasons (March - July - May / MAM), dry season (June - July - August / JJA) and In between (September -

October - November / SON).

Table 6 Seasonal Trends

\begin{tabular}{lccccccccc}
\hline Season & \multicolumn{3}{c}{$\begin{array}{c}\text { Semarang } \\
\text { Decade }\end{array}$} & II & I & II & III & I & \multicolumn{2}{c}{$\begin{array}{c}\text { Palembang }^{2} \\
\text { Decade }\end{array}$} \\
\cline { 2 - 10 } & I & II & II & III \\
\hline DJF & -8.2648 & -2.5043 & -14.54 & $\mathbf{0 . 8 5 0 5}$ & -11.105 & -7.6673 & $\mathbf{1 4 . 4 4 8}$ & $\mathbf{2 . 6 9 8}$ & $\mathbf{1 . 0 5 7 4}$ \\
MAM & -3.6121 & $\mathbf{5 . 9 5 7}$ & -1.8097 & $\mathbf{3 . 6 7 6 8}$ & $\mathbf{2 . 0 7 4 7}$ & -16.211 & -3.9879 & $\mathbf{2 . 0 7 2 3}$ & -3.5325 \\
JJA & -3.8057 & -1.992 & $\mathbf{7 . 5 9 0 5}$ & $\mathbf{2 . 6 1 2 1}$ & $\mathbf{5 . 2 3 4 3}$ & -6.1673 & $\mathbf{8 . 8 7 0 7}$ & $\mathbf{2 . 7 7 8 8}$ & $\mathbf{1 . 0 3 9 4}$ \\
SON & $\mathbf{7 . 2 9 7 8}$ & $\mathbf{1 . 0 6 9 5}$ & -1.9034 & $\mathbf{0 . 7 3 1 3}$ & $\mathbf{2 . 0 7 4 7}$ & $\mathbf{1 6 . 2 1 1}$ & $\mathbf{6 . 2 1 9 4}$ & -5.2071 & $\mathbf{3 . 9 5 0 3}$ \\
\hline
\end{tabular}

${ }^{1}$ Stasiun Meteorology Ahmad Yani; ${ }^{2}$ Station Climatology Belawan; ${ }^{3}$ Stasisun Climato logy Kenten;

Table 7 Test of Different Rainfall in Rainy Season

\begin{tabular}{|c|c|c|c|c|c|c|c|c|}
\hline \multirow[b]{2}{*}{ Decade } & \multicolumn{3}{|c|}{ Semarang } & \multicolumn{2}{|c|}{ Medan } & \multicolumn{3}{|c|}{ Palembang } \\
\hline & t calc & $\begin{array}{c}t \\
\text { table }\end{array}$ & decision & $\begin{array}{c}\text { Asymp. } \\
\text { Sig } \\
\text { (2 tailed)* }\end{array}$ & decision & t calc & table & decision \\
\hline III-II & $-0,466$ & 2.262 & Accept $\mathrm{H}_{0}$ & 0,959 & Accept $\mathrm{H}_{0}$ & $-0,029$ & 2.262 & Accept $\mathrm{H}_{0}$ \\
\hline II-1 & $-0,082$ & 2.262 & Accept $\mathrm{H}_{0}$ & 0.508 & Accept $\mathrm{H}_{0}$ & $-0,659$ & 2.262 & Accept $\mathrm{H}_{0}$ \\
\hline III-1 & $-0,429$ & 2.262 & Accept $\mathrm{H}_{0}$ & 0,959 & Accept $\mathrm{H}_{0}$ & $-0,483$ & 2.262 & Accept $\mathrm{H}_{0}$ \\
\hline
\end{tabular}

* Wilcoxon Sihned Ranks Test (Not Normal distribution)

Table 8 Test of Different Rainfall in the Dry Season

\begin{tabular}{|c|c|c|c|c|c|c|c|c|c|}
\hline \multirow[t]{2}{*}{ Decade } & \multicolumn{3}{|c|}{ Semarang } & \multicolumn{3}{|c|}{ Medan } & \multicolumn{3}{|c|}{ Palembang } \\
\hline & $\begin{array}{c}\mathbf{t} \\
\text { calc. }\end{array}$ & $\begin{array}{c}\text { t } \\
\text { table }\end{array}$ & decision & $\begin{array}{c}\mathbf{T} \\
\text { calc }\end{array}$ & $\begin{array}{c}t \\
\text { table }\end{array}$ & decision & $\begin{array}{c}\mathrm{t} \\
\text { calc }\end{array}$ & $\begin{array}{c}t \\
\text { table }\end{array}$ & decision \\
\hline III-II & $-0,656$ & 2.262 & Accept $\mathrm{H}_{0}$ & $-0,485$ & 2.262 & Accept $\mathrm{H}_{0}$ & $-0,198$ & 2.262 & Accept $\mathrm{H}_{0}$ \\
\hline II-I & $-0,693$ & 2.262 & Accept $\mathrm{H}_{0}$ & 1,336 & 2.262 & Accept $\mathrm{H}_{0}$ & $-0,490$ & 2.262 & Accept $\mathrm{H}_{0}$ \\
\hline III-1 & $-0,205$ & 2.262 & Accept $\mathrm{H}_{0}$ & 0.966 & 2.262 & Accept $\mathrm{H}_{0}$ & $-0,951$ & 2.262 & Accept $\mathrm{H}_{0}$ \\
\hline
\end{tabular}

Table 9 Test of Different Rainfall in SON and MAM

\begin{tabular}{|c|c|c|c|c|c|c|c|c|c|}
\hline \multirow[t]{2}{*}{ Dekade } & \multicolumn{3}{|c|}{ Semarang } & \multicolumn{3}{|c|}{ Medan } & \multicolumn{3}{|c|}{ Palembang } \\
\hline & $\begin{array}{c}\mathrm{t} \\
\text { calc }\end{array}$ & $\begin{array}{c}\mathrm{t} \\
\text { table }\end{array}$ & decision & $\begin{array}{c}\mathrm{T} \\
\text { calc }\end{array}$ & $\begin{array}{c}\mathrm{t} \\
\text { table }\end{array}$ & decision & $\begin{array}{c}\mathrm{t} \\
\text { calc }\end{array}$ & $\begin{array}{c}\mathrm{t} \\
\text { table }\end{array}$ & decision \\
\hline MAM & & & & & & & & & \\
\hline III-II & $-0,537$ & 2.262 & Accept $\mathrm{H}_{0}$ & 0,16 & 2.262 & Accept $\mathrm{H}_{0}$ & 0,584 & 2.262 & Accept $\mathrm{H}_{0}$ \\
\hline II-I & 0,705 & 2.262 & Accept $\mathrm{H}_{0}$ & 1,466 & 2.262 & Accept $\mathrm{H}_{0}$ & 0,719 & 2.262 & Accept $\mathrm{H}_{0}$ \\
\hline III-1 & 0,98 & 2.262 & Accept $\mathrm{H}_{0}$ & 1,577 & 2.262 & Accept $\mathrm{H}_{0}$ & 1,649 & 2.262 & Accept $\mathrm{H}_{0}$ \\
\hline SON & & & & & & & & & \\
\hline III-II & $-0,300$ & 2.262 & Accept $\mathrm{H}_{0}$ & $-0,548$ & 2.262 & Accept $\mathrm{H}_{0}$ & 0,687 & 2.262 & Accept $\mathrm{H}_{0}$ \\
\hline II-I & 0,781 & 2.262 & Accept $\mathrm{H}_{0}$ & 1,479 & 2.262 & Accept $\mathrm{H}_{0}$ & 0,750 & 2.262 & Accept $\mathrm{H}_{0}$ \\
\hline III-1 & 0,423 & 2.262 & Accept $\mathrm{H}_{0}$ & 0,754 & 2.262 & Accept $\mathrm{H}_{0}$ & 1,903 & 2.262 & Accept $\mathrm{H}_{0}$ \\
\hline
\end{tabular}

The results of analysis (table 6) note that the rainfall trend during peak rainy season / DJF in Semarang city of rain has decreased. While in Medan the peak of the rainy season occurred in the SON months, with a trend that continues to increase from the period I, II and III. In the city of Palembang, seasonal trends tend to rise in all seasons in each period, except in the MAM month which has a negative trend in period I and III, as well as period II in SON.

While the dry season / JJA rainfall in Semarang City decreased in the period I and II, while the third period of rainfall trend is positive. In the city of Medan JJA months is the beginning of the rainy season with a positive trend in the period I and II while experiencing increasing in the period III.
Table $7.8 \& 9$ is the result of the test of the seasonal rainfall data (DJF / MAM / JJA / SON) with the value of t-statistic below the critical point ( $t$ table) so the decision taken is to accept $\mathrm{HO}$, it is concluded that the average of bulk Seasonal rain between periods did not differ significantly.

\subsubsection{Rainfall Extreme Events Identification}

The identification of extreme climate is part of the effort to identify climate change in a region. Identified rainfall is heavy rainfall category $(>50 \mathrm{~mm} /$ day) and very heavy category $(>100 \mathrm{~mm} /$ day).. 

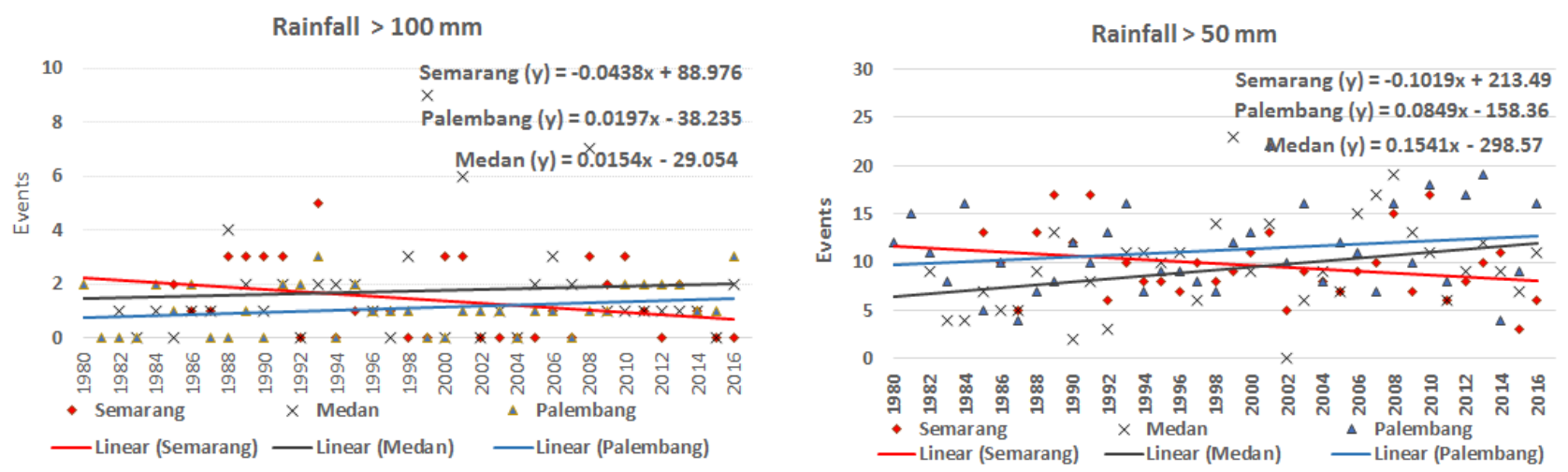

Fig. 5. Rainfall Trends over $50 \mathrm{~mm} /$ day and $100 \mathrm{~mm} /$ day

Figure 5 shows an increase in extreme climate of rainfall above $50 \mathrm{~mm} /$ day and above $100 \mathrm{~m} /$ day in Medan City and Palembang City, while in heavy rainfall trend and very heavy drop in Semarang City.

\section{Conclusions}

- Trends in air temperature in Semarang City, Medan City and Palembang increased by $0.0279^{\circ}$ $\mathrm{C} / \mathrm{yr}, 0.00331^{\circ} \mathrm{C} / \mathrm{yr}(1982-2016) 0.0323^{\circ} \mathrm{C} /$ year (1980-2016).

- Trend of rainfall in the three cities showed no real difference between periods, but has a tendency to fall in the city of Semarang and the tendency to ride in the city of Medan and the city of Palembang.

- $\quad$ Trend of heavy and very heavy rainfall in the city of Medan and Palembang, while the downward trend in the city of Semarang.

- Changes in temperature trends become a strong indicator of climate change occurring in all three cities.

\section{References}

1. Mercy Corps, ACCCRN, URDI, ISET. Kajian kerentanan dan adaptasi terhadap perubahan iklim di kota semarang 2010. 2010.

2. Arifin B. Pemanasan Global dan Ketahanan Pangan Nasional. J Pangan. 2009;Edisi No 5.

3. Yananto A, Dewi S. Analisis Kejadian El Nino Tahun 2015 dan Pengaruhnya Terhadap Peningkatan Titi Api di Wilayah Sumatera dan Kalimantan, Indonesia. 2016;17(1):11-19.

4. Kebencanaan I, Teraktual B. Info bencana. 2015;(September):1-4.

5. Kementerian Perencanaan Pembangunan Nasional/Badan Perencanaan Pebangunan Nasional (Bappenas). Rencana Aksi Nasional Adaptasi Perubahan Iklim. 2014.

6. OECD. Cities and climate change: national governments enabling local action. Change. 2014:276. doi:10.1787/9789264091375-en.

7. IPCC. Climate Change 2007 The Physical Science Basis The. Vol 53.; 2007. doi:10.1017/CBO9781107415324.004.

8. Aldrian E, Budiman, Mimin Karmini. Adaptasi dan Mitigasi Perubahan Iklim di Indonesia. 2011;(November).

9. IPCC. Summary for Policymakers.; 2014. doi:10.1017/CBO9781107415324.

10. Aldrian E, Dwi Susanto R. Int J Climatol. 2003;23(12):1435-1452. 